\title{
C Research Square \\ Understanding the evolution of cleavage patterns in early embryonic development
}

\author{
Bruno C. Vellutini
}

José M. Martín-Durán

Andreas Hejno

\section{Video Abstract}

Keywords: Bryozoa, Cyphonautes, Spiral cleavage, Cell lineage Larva, MAPK, Gene expression, Molecular patterning

Posted Date: November 20th, 2020

DOI: https://doi.org/10.21203/rs.3.rs-112272/v1

License: (c) (i) This work is licensed under a Creative Commons Attribution 4.0 International License.

Read Full License 


\section{Abstract}

A new study shows that a novel embryonic cleavage pattern can evolve without affecting other developmental traits. But let's start at the beginning. The earliest stages of animal development - the moments following fertilization of the egg - involve a sequence of cell divisions that will eventually turn a zygote into a multicellular embryo. This process is termed_cleavage_. Two cells become four. Four cells become eight. Etcetera. But it's not just the addition of new cells that is important in this process it's also their orientation. Just as there are all shapes and sizes of animals, the pattern of early cell division varies across different organisms. In some animals, these cleavage patterns play the crucial role of precisely positioning early embryonic cells in just the right way. A single misplaced cell can have catastrophic consequences for the growing embryo. So what happens when an organism evolves a new cleavage pattern? According to a study carried out by scientists in Norway, the answer is: not much. Bryozoans are tiny, filter-feeding, marine invertebrates that belong to a large group of animals exhibiting spiral cleavage. Interestingly, this cleavage pattern has been evolutionarily conserved for millions of years across many animal lineages - from clams to worms. But bryozoans appear to have lost this trait that defines their closest relatives and replaced it with their own, unique geometry. Focusing on this group, and attempting to understand the consequences of this switch, the research team compared the newly evolved bi-radial cleavage pattern found in bryozoans with features of the ancestral spiral state. Close inspection of molecular patterning and embryonic cell orientation turned up a surprising result. It turns out, even though the newly adopted bi-radial cleavage pattern appears drastically different compared to the ancestral morphology, patterns of gene expression and cell fate have remained largely unaffected. These seemingly connected traits are evolving independently. Although focusing on an obscure, marine invertebrate, this discovery has implications for understanding how embryonic development evolves and orchestrates the great diversity of animal forms that exist today. 